\title{
Soil and Sand Mining: Causes, Consequences and Management
}

\author{
M. Naveen Saviour ${ }^{1}$ and P. Stalin ${ }^{2}$ \\ ${ }^{1}$ Research Scholar, ${ }^{2}$ Professor, Department of Soil Science and Agricultural Chemistry, Tamil Nadu \\ Agricultural University, Coimbatore, Tamil Nadu, India- 641003
}

\begin{abstract}
Sand is not only a precious mineral but also protecting the environment, buffer against strong tidal waves and storm, habitat for crustacean species and marine organisms, used for making concrete, filling roads, building sites, brick-making, making glass, sandpapers, reclamations, and in our tourism industry in beach attractions. Sand mining is the process of removal of sand and gravel where this practice is becoming an environmental issue as the demand for sand increases in industry and construction. Topsoil is an essential component in abandoned mines for growth of vegetation and has to be preserved for post-mining land reclamation. Physico-chemical parameters and concentration of heavy metals $\mathrm{Pb}^{2+}, \mathrm{Zn}^{2+}, \mathrm{Ni}^{2+}, \mathrm{Co}^{2+}, \mathrm{As}^{3+}, \mathrm{Cu}^{2+}, \mathrm{Fe}^{2+}, \mathrm{Mn}^{2+}$ and $\mathrm{Sn}^{2+}$ were analyzed in mined soil areas and found that most parameters and metals concentration exceeds the permissible limit and that ex-mining catchment has a high pollution potential. Reclamation strategies of tree planting, amendments like tank silt, poultry litters and growing bio fuel crops are recognised for its ability to restore the soil fertility, build the eco-system and arrest soil erosion. Scientific mining operations accompanied by ecological restoration and regeneration of mined wastelands and judicious use of geological resources, with search for eco-friendly substitutes and alternatives must provide sensational revelation to the impact of mining on human ecosystem.
\end{abstract}

Keywords - Top soil, soil properties, water quality, environmental issue, reclamation

\section{INTRODUCTION}

In almost every mineral bearing region, soil mining and land degradation have been inseparably connected. Unscientific mining has caused degradation of land, accompanied by subsidence and consequential mine fires and disturbance of the water table leading to topographic disorder, severe ecological imbalance and damage to land use patterns in and around mining regions (Ghose, 1989). Topsoil is an essential component in abandoned mines for growth of vegetation and has to be preserved for post-mining land reclamation. The issue is the preservation of topsoil (stockpiling) in the restoration of mined land. This problem is acute in India and large areas are continually becoming unproductive every year (Kundu and Ghose, 2000). Physico- chemical parameters and concentration of heavy metals $\mathrm{Pb}^{2+}, \mathrm{Zn}^{2+}, \mathrm{Ni}^{2+}, \mathrm{Co}^{2+}$, $\mathrm{As}^{3+}, \mathrm{Cu}^{2+}, \mathrm{Fe}^{2+}, \mathrm{Mn}^{2+}$ and $\mathrm{Sn}^{2+}$ were analyzed in mined soil areas and found that most parameters and metals concentration exceeds the permissible limit and concluded that ex-mining catchment has a high pollution potential due to mining activities (Ashraf et al., 2010). The mining of sand resources from rivers and ex-mining areas is a common practice and may lead to destruction of public assets as well as impacts or increase stress on commercial and non commercial living resources that utilize these areas (Ashraf et al., 2011). Tree planting, amendments like tank silt, poultry litters and growing bio fuel crops are recognised for its ability to restore the soil fertility, build the eco-system and arrest soil erosion (Lugo et al., 1993). Scientific mining operations accompanied by ecological restoration and regeneration of mined wastelands and judicious use of geological resources, with search for eco-friendly substitutes and alternatives must provide sensational revelation to the impact of mining on human ecosystem (Surender Singh Chauhan, 2010).

\section{SCENARIO OF SOIL MINING IN INDIA}

Mining is a major contributor (2'nd) to the national GDP (4\%) occupying 36 lakh hec. $(0.11 \%)$ of total land area $(329 \mathrm{~m} \mathrm{ha})$ and providing employment generation $(4 \%)$ for 1.1 million people of the country and in Tamil Nadu the mining area is around 7,000 hec. with $1 \%$ of total area. India recognizes that mining, unless properly regulated, can have adverse environmental and social consequences. It seems that the illegal miners are omnipotent, omnipresent and omniscient, as the government the supposed to be almighty is on their side. The reports on illegal mining across the states and its adverse environmental impact deserve a place in newspapers daily almost. Illegal sand excavation by mafias across major river basins where sand was mined in order to cater to the construction need of the local villages and government offices. Since the 
rivers had sand all over their pathways, ground water table all along their winding routes was kept intact. Due to the over exploitation of river sand, the watercourse has become lower than the level of irrigation canals and hence, sthe irrigation canals get water only when the river is flooded. As a result, the local tanks that depend upon the river for water remain dried all through the years, except the years that have heavy downpour. Thus, over exploitation of river sand results in the destruction of agricultural practices, across the districts and state.

\section{SAND AND SOIL MINING- DEFINITION/ PROCESS}

UNEP (1992) describes sand mining as "the temporary or permanent lowering of the productive capacity of land". "Mining is essentially a destructive development activity where ecology suffers at the altar of economy" (Surender Singh Chauhan, 2010).

First of all, the soil mass is scraped from upper 2 to 3 meters, which contains mostly clay, silt and sandand is purposely saved and stacked aside in heaps. During sand extraction, topsoil layer is peeled and stacked aside and exposed sand is excavated to a depth of 10-12 m. Afterwards, stacked topsoil is spread and mixed with sand bed. As mining proceeds further, the mined fields are handed over to the owner for cultivation. Thick column of sand (light grey) removed and overlying top soil cover (dark grey) pushed down the slope to evenly spread over sandpit. After spreading and mixing top soil with sand, the field is compacted, leveled and bunded to commence cultivation.

\section{CONSEQUENCES OF MINING IN RELATION TO SOIL PROPERTIES}

\subsection{Effect of sand mining on infiltration rate}

Steady Infiltration Rate (IR) was measured in original un-mined and rehabilitated soils by double ring method. Steady IR of original soil was generally low and lead to water logging resulting in soil aeration problems. Steady IR in freshly rehabilitated soil (0 years) was very high i.e. $97.5 \mathrm{~cm} /$ day. This was due to marked change in soil texture resulting in mixing topsoil with sand bed. Steady IR of rehabilitated soil for 3-5 years ranged from $6.5-8.2 \mathrm{~cm} /$ day. Though these values are higher than the original un-mined soils still these are in the optimum range for most of agricultural crops. Thus, improvements in infiltration rate and soil aeration have opened new sorption of crop diversification in rehabilitated soils (Gurubachan Singh et al., 2007)

\subsection{Assessment of soil properties deterioration in storage mounds due to erosion}

In open-cast mining, Jharkhand, soil properties of unmined soil were found to be greyish brown in colour, of sub-angular blocky structure, sticky and plastic with smooth boundary. In the case of soil dumps of different ages, these were found to be light greyish brown in colour, single grain structure, non-sticky and non-plastic and having many vertical tubular pores. It appears that due to the mixing of different soil horizons during mining, the soil profile changed to a great extent (Ghosh, 2002).

The particle size analysis reveals that sand particles increased, and silt and clay decreased with respect to unmined soil. This trend may be due to increased erosion of aggregates and consequently a high rate of infiltration. Sand was found to increase from $66.3 \%$ to $72.2 \%$ with the increase in age of the soil dumps, whereas silt and clay particles decreased from 25.17 to $22.0 \%$ and $8.6 \%$ to $5.8 \%$ respectively. The soil dumps of up to six years of age were found to be sandy loam in texture, and gradually changed to loamy sand after that period. The bulk density of soil dumps was found to increase gradually from 1.66 to 1.72 $\mathrm{Mg} \mathrm{\textrm {m } ^ { - 3 }}$ with increasing age of the dumps.

The high bulk density of the soil dumps may be attributed to the use of heavy machinery. This has a serious implication for subsequent changes in soil properties, because gaseous diffusion is made more difficult. Thus, restrictions on growth of deep-rooted plants may be one of the reasons for stagnation of plant succession at the shrub stage. Field moisture, field capacity and water holding capacity of different soil dumps of different ages were found to decrease from $9.5 \%$ to $7.2 \%, 14.7 \%$ to $13.1 \%$ and $36.6 \%$ to $32.6 \%$ respectively.

\subsection{Assessment of Physico chemical \& Ionic exchange) deterioration}

In dumps of one to six years of age, $\mathrm{pH}$ varied from 6.14 to 6.05 which is within the optimal range ( $\mathrm{pH} 6$ to 7) for plant growth. But in ten-year-old dumps, $\mathrm{pH}$ changed to 5.88 The EC of the soil dumps was found to decrease from 0.36 to $0.26 \mathrm{dSm}^{-1}$. CEC was found to be lower and decreasing with increasing age (Kundu and Ghose 2000).

The sodium absorption ratio (SAR) was found to be between 0.12 to 0.15 . The organic carbon level in soil dumps of different ages was found to be very poor and varied from 0.38 to 0.26 . The decrease in organic carbon from unmined soil to the one year old dumps was about $47 \%$, to the one- to six-year-old dumps, $23 \%$ and to the six- to ten-year-old dumps, $6 \%$. The total nitrogen in the soil dumps was also found to be very low, in the range 0.03 to $0.01 \%$. The deficiency of nitrogen in mine soil is often due to the 
lack of adequate mineralizable organic nitrogen and lower mineralization rates. A narrower range of $\mathrm{C} / \mathrm{N}$ ratio was found in the one- to six-year-old dumps as compared to the nine- to ten year-old dumps.

\subsection{Deterioration of soil available macro and micro nutrients and microbeS}

The available micronutrients (NPK) were found to decrease greatly in comparison to unmined soil and also decreased with increasing soil dump age Available nitrogen was found to decrease rapidly in one-year-old dumps to $31 \%$, to gradually decrease to $27 \%$ in dumps up to six years of age, and after that to 5\%, which became a stable condition (Ghosh, 2002). A similarly decreasing trend was also observed in available phosphorous $(23 \%-11 \%-6 \%)$ and potassium $(28 \%-18 \%-11 \%)$.

The concentrations of available (DTPA extractable) micronutrients such as $\mathrm{Fe}, \mathrm{Mn}, \mathrm{Cu}$ and $\mathrm{Zn}$ were found to decrease in soil dumps of one year of age. But, Fe and Mn were found to increase with age of soil dump and ultimately to exceed the concentration in unmined soil. The populations of bacteria, actinomycetes and fungi in one-year-old dumps were found to be five to eight times lower than in the unmined soil and also gradually decreased with increasing age of dump (Kundu and Ghose 2000). The decreases in popula- tion of bacteria, actinomycetes and fungi from the one- to ten-year-old dumps were $63 \%, 55 \%$ and $45 \%$ respectively. The decreases may be due to the presence of lower concentrations of organic matter, moisture and other edaphic factors.

\subsection{Physical impacts}

\section{IMPACT OF MINING ACTIVITIES}

These impacts may cause: (1) the undercutting and collapse of river banks, (2) the loss of adjacent land and/or structures, (3) upstream erosion as a result of an increase in channel slope and changes in flow velocity, and (4) downstream erosion due to increased carrying capacity of the stream, downstream changes in patterns of deposition, and changes in channel bed and habitat type.

\subsection{Water quality and heavy metals contamination}

Mining and dredging activities, poorly planned stockpiling and uncontrolled dumping of overburden, and chemical/fuel spills will cause reduced water quality for downstream users, increased cost for downstream water treatment plants and poisoning of aquatic life. In ex-mining area of Peninsular Malaysia the physiochemical parameters and concentration of heavy metals $\mathrm{Pb}^{2+}, \mathrm{Zn}^{2+}, \mathrm{Ni}^{2+}, \mathrm{Co}^{2+}, \mathrm{As}^{3+}, \mathrm{Cu}^{2+}, \mathrm{Fe}^{2+}$, $\mathrm{Mn}^{2+}, \mathrm{Sn}^{2+}$ were analyzed and results were compared with interim national water quality standards for Malaysia and found that most of the parameters and metals concentration exceeds the permissible limits set by interim national water quality standards for Malaysia (Ashraf et al., 2010).

In root vegetables and onion grown in old mining area, Rumania heavy metal concentrations varied among different vegetables which may be attributed to differential absorption capacity of vegetables All the heavy metals concentrations were several folds higher in the vegetables from contaminated area ( $\mathrm{R}$ and $\mathrm{M}$ sites) as compared to uncontaminated area (Ref site) The most abundant element in parsley and carrot roots and onion was $\mathrm{Fe}\left(\mathrm{mg} \mathrm{Kg}^{-1}\right.$ fresh matter, *p<0.05) for both reference and contaminated soils. The richest content of Fe was identified in parsley roots, followed by carrot roots and onion, especially for vegetables grown in contaminated soil. $\mathrm{Zn}$ and $\mathrm{Mn}$ concentrations in parsley and carrot roots and onion are very closely as values one from another, richer in vegetables grown in contaminated soils, especially for the ones from $\mathrm{R}$ area (Monica Harmanescu et al., 2011)

For parsley roots from $\mathrm{R}$ area, $\mathrm{Zn}$ concentration exceeds maximum allowable limit (MAL) in these vegetables. The highest concentration of $\mathrm{Cu}$ was detected also in parsley roots, when $\mathrm{Cu}$ concentration exceeds MAL. The $\mathrm{Cu}$ concentrations in parsley and carrot roots from reference area are higher than in onion. Generally, in vegetables from contaminated $\mathrm{M}$ area $\mathrm{Cu}$ concentrations are higher than in contaminated $\mathrm{R}$ area. Parsley roots accumulate the highest concentration of $\mathrm{Ni}$ in contaminated areas. $\mathrm{Pb}$ was identified in all vegetables from all areas. In reference area the $\mathrm{Pb}$ concentrations in all investigated vegetables are small and away of MAL.

\subsection{Ecological impacts}

Mining which leads to the removal of channel substrate, resuspension of streambed sediment, clearance of vegetation, and stockpiling on the streambed, will have ecological impacts. These impacts may have an effect on the direct loss of stream reserve habitat, disturbances of species attached to streambed deposits, reduced light penetration, reduced primary production, and reduced feeding opportunities.

Offin river basin, Ghana (Dhakwa et al., 2005) were studied due the effects of gold mining operations with respect to fish community on the aquatic eco- system. Fish in the dredging area had accumulated with higher concentration of trace metals in their tissues. The fish fauna comprised of 15 species 
belonging to 10 genera and 7 families. Out of all, only the Characid Brycinus nurse (R) occurred in all and the remaining species were not found in all.

\section{ENVIRONMENTAL \& SOCIO- ECONOMIC IMPACT OF MINING}

\subsection{Acid Mine Drainage- Threat to water resources}

Acid mine drainage is a concern at many metal mines, because metals such as gold, copper, silver and molybdenum, are often found in rock with sulfide minerals. When the sulfides in the rock are excavated and exposed to water and air during mining, they form sulfuric acid. This acidic water can dissolve other harmful metals in the surrounding rock. If uncontrolled, the acid mine drainage may runoff into streams or rivers or leach into groundwater. Many streams impacted by acid mine drainage have a $\mathrm{pH}$ value of 4 or lower similar to battery acid. Plants, animals, and fish are unlikely to survive in streams such as this. Acid mine drainage also dissolves toxic metals, such as copper, aluminum, cadmium, arsenic, lead and mercury, from the surrounding rock. Carried in water, the metals can travel far, contaminating streams and groundwater for great distances.

\subsection{Socio-ecological impacts}

Ten people interviewed in mining area of East Konga of Iceland indicated loss or reduction of farmlands as a major impact of gravel mining. Other significant impacts of gravel mining in the area obtained as views include pits serving as breeding grounds for mosquitoes and spread of other diseases, erosion and loss of vegetation, loss of economically important trees, as well as roots of conflicts (Musah and Kjorn, 2007).

In Ratnapura district, Sabaragamuwa province of Sri Lanka (Sri Lankan Net W water report, 2010) like many other minerals sand has become a scare resource due to high demand for constriction and developmental activities. Rivers in Sri Lanka are under immense pressure due to various kinds of human activities among which indiscriminate extraction of sand is the most disastrous one. Out of the 7 sites four ranked as highly damaged and the rest as moderately damaged. There were no sites ranked as limited or zero damage.

\section{RECLAMATION/ MANAGEMENT MEASURES}

The major reclamation strategies for soil and sand mined areas are

1. Replacement of overburden and grading

2. Topsoil replacement

3. Inoculating soil $\mathrm{N}$-fixing and $\mathrm{P}$ - solubilising microbes

4. Sub-soiling for 30 to $60 \mathrm{~cm}$ depth should be done before planting seeds

5. Significant fertilizer application for the establishment and maintenance of vegetation.

6. Soil amendments should be applied before seeding or planting. Common soil amendments used are biosolids, compost, manure, lime and coal combustion by products.

7. Selecting vegetation species suited to the properties of minesoil, tolerate and establish quickly in harsh condition, control erosion and have fast growth.

8. Irrigation.

9. Mulching should be done after seeding to improve moisture holding capacity

10. Erosion control measures

\subsection{Reclamation of mine lands through afforestration}

The reclaimed soils produced significantly lesser yields in the initial one or two years. Sand mining from agricultural fields should be permitted provided the mine lands must be returned to agricultural land use after concurrent reclamation under guidance and monitoring of agricultural experts. Choice of species like Eucalyptus camaldulensis, Eucalyptus tereticornis, Acacia nilotica, Acacia leucopholea, Grevilea robusta, Cenchurs ciliaris, Azadirachta indica, Dalbergia sisoo and Agave species with rapid biomass accumulation should be selected for efficient $C$ sequestration. In south India, the results of the overall survival percentage of tree species in the first year of the plantation, reported quite encouraging in all the terraces, averaging around $80 \%$ (Suresh and Silori, 2011).

Among the selected five species, L. leucocephala attained the maximum average height. From an average height of $0.27 \mathrm{~m}$ in 2003 to $4.25 \mathrm{~m}$, reporting nearly 16 times increase in November 2007. This was followed by $P$. pinnata ( 9 time increase from $0.19 \mathrm{~m}$ to $1.75 \mathrm{~m}$ ). A. nilotica reported the least growth, reporting about 3.5 times increase in height in 4.5 years duration.

Burger and Zipper (2002) reported that restoring forests on surface-mined land is challenging; however, reforestation research by Virginia Tech's Powell River Project since 1980 shows that restored forests can be equally or more productive than the native forests removed by mining. The critical factors that affect survival and growth of trees are spoil type, compaction, slope aspect and position, and competition from 
ground cover grasses and legumes. Reforestation silviculture seeks to stimulate natural processes known as forest succession.

\subsection{Re- vegetating Bio-energy Crops on Mine Lands}

In Powell river, Virginia, Bio-fuel species comparisons were begun at the Powell River Project in 2007 to determine yield capacity of several feedstock species with potential suitability for revegetating mined land. Initial survival and harvest data from the 2008 growing season suggested miscanthus might be well-suited to production on mine lands. Both switch grass first harvest yields (1.75 ton/acre) and over-winter losses (55\%) were greatest among seeded species. Native grasses such as switch grass currently appear to be front runners for bioenergy crops on reclaimed mine sites (Fike et al ., 2010).

\subsection{Application of tank silt for improving mined soil lands}

In Krishna and Gothavari river basins of Andhra the $\mathrm{pH}$ of the tank silt ranged from 6.5 to 8.5. $\mathrm{pH}$ of the tank silt varied with depth. Except Relakunta all the tanks recorded $\mathrm{pH} 7.0$ and above, while Rudragudum recorded the highest (8.5). $\mathrm{pH}$ has high relevance and some crops are very sensitive (Osman, 2007). If soils with high $\mathrm{pH}$ receive more tank silt, it might affect the crop productivity adversely. EC was found to be normal $\left(<0.4 \mathrm{dS} \mathrm{m}{ }^{-1}\right)$ and within safe limits for all the tanks. Net income with and without application of tank silt obtained for various crops reported savings on fertilizers ranging from Rs. 2,500 to Rs. 3,750 per hectare in case of cotton, which is a major crop grown in this area. The increase in the yield of cotton was to the tune of $1000 \mathrm{~kg} \mathrm{ha}^{-1}$. The maximum benefit was obtained in chillies and cotton and the gain was negligible in turmeric and no gain was observed for maize.

\subsection{Poultry Litter as soil amendment in reforestation and revegetation}

In Surface Mine Land reclamation in Alabama shows the potential value of poultry litter as a soil amendment in reforestation and revegetation of surface coal mine land to mitigate nonpoint source water pollution impacts in the surrounding watershed. Initial on-site soil samples revealed $\mathrm{pH}$ ranged from 3.3-4.2 (Sibley et al., 1996). The site was amended with finely ground limestone at rates ranging from four to eight tons per acre, effectively raising the soil $\mathrm{pH}$ to 4.9 . A slurry pond with a $\mathrm{pH}$ of less than three was eliminated, with the entire project effectively contoured into one watershed, raising runoff $\mathrm{pH}$ to 4.5. Even the high rates of litter have had no negative effects at this point on ground cover or tree survival, and surface runoff has been nearly eliminated. Additionally, ground water sampling has not indicated a significant increase in nitrates (NO3).

\section{CONCLUSION}

Soils mining significantly affect the soil properties. A high level lobbying committee must be formed and the stockpiled materials should be selectively placed and protected from erosion, compaction and contamination. Weak governance and rampant corruption are facilitating illegal mining posing depletion of water resources needs to enforce laws in an efficient and unbiased way. Restoration, Rehabilitation, Revegetation and Afforestration measures with correct choice of tree species, planting techniques and appropriate proportions of soil amendments can restore soil quality overtime.

\section{REFERENCES}

[1]. Ashraf, M.A., Maah M.J and Yusoff, I.B. 2010. Study of Water Quality and Heavy Metals in

[2]. Soil \& Water of Ex-Mining Area Bestari Jaya, Peninsular Malaysia.

[3]. Ashraf, M.A., Maah, M.J., Yusoff, I., Wajid, A and Karama. M. 2011. Sand mining effects,

[4]. causes and concerns: A case study from Bestari Jaya, Selangor, Peninsular Malaysia.

[5]. $\quad$ Scientific Research and Essays Vol. 6(6), pp. 1216-1231.

[6]. Dhakwa, C.A.,Biney, C.A and K.A.A. De Graft Johnson. 2005. Impact of mining operations

[7]. on the ecology of river Offin, Ghana. West African Journal of Applied Ecology, Vol. 7.

[8]. Ghose, M.K. 1989. Land reclamation and protection of environment from the effect of coal mining operation. Mine-tech, 10 (5), 35-39.

[9]. Gurubachan Singh, K. K. Mehta., R.C. Sharma.K.L Chawla., P.K. Joshi., N.P. Yaduvanchi. 2005. Technical bulletin on Sand mining/no mining in Agricultural fields in Haryana.

[10]. Jafaru Adam Musah and Bjorn H. Barkarson. 2009. Assessment of sociological and ecological impacts of sand and gravel mining- A case study of East Gonja district (Ghana) and Gunnarsholt (Iceland). Land Restoration Training Programme, Keldnaholt, 112 Reykjavík, Iceland.

[11]. James A. Burger and Carl E. Zipper. 2002. Reclamation Guidelines for Powell river project.

[12]. How to restore forests on surfice- mined land, Virginia.

[13]. John Fike, John Galbraith, Chris Teutsch, David Parrish and Carl Zipper. 2010. Progress report of POWELL RIVER REPORT, VIRGINIA. Herbaceous Crops for a Biofuels/ Bioproducts Industry on Reclaimed Mine Lands.

[14]. Kundu, N.K. and Ghose, M.K. 2000. Probable impacts on land-use due to opencast coal mining. Indian Jr. Environmental Studies and Policy, 21 (2), 87-96.

[15]. Lugo, AE., Parrota, J and Brown, S. 1993. Loss in species caused by tropical deforestration and their recovery through management. Amb. 22: 106-109.

[16]. Monica Harmanescu, Liana Maria Alda, Despina Maria Bordean, Ioan Gogoasa and Lossif Gergen. 2011. Heavy metals health riskassessment for population via consumption of vegetables grown in old mining area; a case study: Banat County, Romania. Chemistry Central Journal, 5:64.

[17]. Osman, M., Ramakrishna, Y.S. and Shaik Haffis. 2007 "Rejuvenating Tanks for Self- Sustainable Rainfed Agriculture 
in India" Agriculture Situation in India, Vol. (LXIV): 67-70.

[18]. Sibley, L., A. William Dozier., James O Donald., David G. Himelrick, John H Wilhoit and E.S. Lyle. 1996. Poultry litter looks promising in surface mine land reclamation. Highlights of Agricultural Research, USA. Vol. 43, No. 2.

[19]. Sri Lankan Net W water report, 2010. Impact of river sand mining in Ratnapura district in

[20]. Sabaragamuwa province.

[21]. Surender Singh Chauhan. 2010. Mining, Development and Environment: A Case Study of Bijolia Mining Area in Rajasthan, India. $J$ Hum Ecol, 31(1): 65-72.

[22]. Suresh Chauhan and C. S. Silori. 2011. An evaluation of successful reclamation of bauxite residue through afforestation activities in south India. Journal of Horticulture and Forestry Vol. 3(7), pp. 214-221.

[23]. United Nation EnvironmentProgramme. 1992. Environmental aspects of selected non ferrous metals $(\mathrm{Cu}, \mathrm{Ni}, \mathrm{Pb}$, As) ore mining. A technical guide, UNEP Technical report series No. 5. 116 PP. 